\title{
Triterpenoids and Phenolics from the Leaves of Ficus hirta Vahl. in Tuyen Quang Province, Vietnam
}

\author{
Tran Duc Dai ${ }^{*}$, Nguyen Thanh Tam², Tran Thi Giang Huong${ }^{1}$, Nguyen Thi Tuyet ${ }^{1}$, Dinh Thuy Van \\ ${ }^{1}$ Tan Trao University. \\ ${ }^{2}$ Institute of Chemistry, Vietnam Academy of Acience and Technology. \\ ${ }^{3}$ Thai Nguen University of Education.
}

\begin{abstract}
How to cite this paper: Tran Duc Dai Nguyen Thanh Tam, Tran Thi Giang Huong, Nguyen Thi Tuyet, and Dinh Thuy Van. (2020) Triterpenoids and Phenolics from the Leaves of Ficus hirta Vahl. in Tuyen Quang Province, Vietnam. International Journal of the Science of Food and Agriculture, 4(2), 138-142.

DOI: $10.26855 /$ ijfsa.2020.06.004
\end{abstract}

Received: March 5, 2020

Accepted: March 30, 2020

Published: April 7, 2020

*Corresponding author: Tran Duc Dai, Tan Trao University.

Email: ducdaitq@gmail.com

\begin{abstract}
Two usane-type triterpenoids as $\alpha$-amyrin acetate (1), $3 \beta$-acetoxy-11 $\alpha$-hydroxy12-ursenes (2) and two phenolics as $p$-coumaric acid (3), isovitexin (4) were isolated from the leaves of Ficus hirta collected in Yen Son district, Tuyen Quang province, Vietnam. Their structures were determined from analysis of MS and 1D-, 2D-NMR spectra data and by comparison with data reported in the literatures.
\end{abstract}

\section{Keywords}

Ficus hirta, triterpenoids, phenolics, $\alpha$-amyrin acetate, $3 \beta$-acetoxy- $11 \alpha$-hydroxy12-ursene, $p$-coumaric acid, isovitexin

\section{Introduction}

The genus Ficus (Moraceae) comprising about 1,000 species grows mainly in tropical and subtropical [1,2]. Where it is traditionally used as a medicinal plant for nephritis, hepatitis, mastitis, bruises, injuries, rheumatism, cough and to promote milk secretion during childbirth, treatment of constipation, postpartum hypogalactia, tumors, and cancer $[2,3,4]$. Certain studies regarding the chemical composition and harmacological activities of $F$. hirta Vahl. reported that benzene derivatives, phenolics, and glycosides of flavonoid are majorly present of the roots $[5,6,7,8]$ and fruits of $F$. hirta [9]. Dao Duc Thien et al. have separated and analyzed the chemical components in the extract of $F$. hirta. The result has identified a new 5- $O$-[ $\beta$-D-apiofuranosyl-( $1 \rightarrow 2)-\beta$-D-glucopyranosyl] bergaptol (1), 9 known compounds [10,11] from the Roots of $F$. hirta and 04 triterpenoid with a new $3 \beta$-hydroxy-11-oxo-olean-12-enyl-3-stearate [12] from leaves of $F$. hirta. This paper reports the isolation and

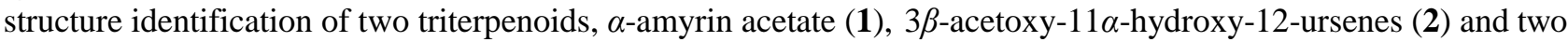
phenolics, $p$-coumaric acid (3), isovitexin (4) from leaves of $F$. hirta collected in Yen Son district, Tuyen Quang province, Vietnam. Their structures were determined from analysis of MS and 1D-, 2D-NMR spectra data and by 
comparison with data reported in the literatures.

\section{Experimental}

\subsection{Plant materials}

The leaves of $F$. hirta were collected in Yen Son district, Tuyen Quang province, Vietnam in December, 2019. Identified at the site by Dr. Nguyen The Hai, Faculty of medicine and pharmacy, Tan Trao University. A voucher specimen (FH-12/2019) is deposited in Center for Pharmacy Practice Accreditation, Tan Trao University.

\subsection{General experimental procedures}

Thin layer chromatog-raphy (TLC) was performed on silica gel $60 \mathrm{~F}_{254}$ aluminum plates $(0.25 \mathrm{~mm}$, Merck, Darmstadt, Germany). TLC spots were viewed at 254, 302 and $366 \mathrm{~nm}$ and visualized by spraying with vanilin-10\% $\mathrm{H}_{2} \mathrm{SO}_{4}$ solution and heating for 5 minutes. Column chromatography was carried out on silica gel 60 (0.040 - 0.063 mm, Merck, Darmstadt, Germany) and Sephadex LH-20 (Amersham Pharmacia Biotech, Tokyo, Japan). HR-ESI-MS was obtained on a Agilent introduces 1,100 Series LC/MSD Trap SL. NMR spectra were taken on a Bruker Avance III 500 spectrometer (Bruker, Fällanden, Switzerland) at Institute of Chemistry, Vietnam Academy of Science and Technology.

\subsection{Extraction and isolation}

The dried leaves of $F$. hirta (4 kg) were ground and extracted three times with methanol-water (95:5, v/v) at room temperature. After the combined extracts, were evaporated under reduced pressure at $45{ }^{\circ} \mathrm{C}$, the residue was suspended in $\mathrm{H}_{2} \mathrm{O}$ and then partitioned in turn between $n$-hexane, ethyl acetate and $n$-butanol, successively. The organic solvents were evaporated to yield the corresponding extracts of $40 \mathrm{~g}, 50 \mathrm{~g}$, and $100 \mathrm{~g}$, respectively.

The $n$-hexane extract $(40 \mathrm{~g})$ was subjected to silica gel column chromatography with a gradient mixture of $n$-hexane: EtOAc (from 50:1 to 1:1, v/v) to give 7 fractions (A-G). Fraction B was repeatedly chromatographed on silica gel column ( $n$-hexane: EtOAc, 15:1, v/v) to afford compound $\mathbf{1}(0,3 \mathrm{~g})$. Fraction $\mathrm{F}$ was chromatographed on silica gel column ( $n$-hexane: EtOAc, 9:1, v/v) and then on Sephadex LH-20 column ( $n$-hexane : $\mathrm{CH}_{2} \mathrm{Cl}_{2}: \mathrm{MeOH}=$ $1: 1: 2)$ to give compound $2(4 \mathrm{mg})$.

The $n$-butanol extract ( $100 \mathrm{~g}$ ) was applied on a silica gel column eluded with (EtOAc: $\mathrm{MeOH}: \mathrm{H}_{2} \mathrm{O}=8: 2: 0.2 \rightarrow$ 3.5:2:0.2) to yield 9 fractions. Fraction 1 was chromatographed on silica gel column $(n$-hexane: EtOAc $=2: 1)$ to give compound $3(2 \mathrm{mg})$. Fraction 7 was chromatographed on silica gel column $\left(\mathrm{CH}_{2} \mathrm{Cl}_{2}: \mathrm{MeOH}=8.5: 1.5\right)$ and then on Sephadex LH-20 column ( $\left.\mathrm{MeOH}: \mathrm{H}_{2} \mathrm{O}=2: 1\right)$ to give compound $4(3 \mathrm{mg})$.

$\boldsymbol{\alpha}$-Amyrin acetate (1): White solid. ${ }^{1} \mathrm{H}-\mathrm{NMR}\left(500 \mathrm{MHz}, \mathrm{CDCl}_{3}\right) \delta_{\mathrm{H}} 5.13(1 \mathrm{H}, \mathrm{t}, J=3.5 \mathrm{~Hz}, \mathrm{H}-12), 4.51(1 \mathrm{H}, \mathrm{m}$, $\mathrm{H}-3), 2.04\left(3 \mathrm{H}, \mathrm{s}, \mathrm{CH}_{3} \mathrm{CO}\right), 1.07(3 \mathrm{H}, \mathrm{s}, \mathrm{H}-27), 1.01(3 \mathrm{H}, \mathrm{s}, \mathrm{H}-26), 0.98(3 \mathrm{H}, \mathrm{s}, \mathrm{H}-25), 0.92(3 \mathrm{H}, \mathrm{d}, J=6.0 \mathrm{~Hz}$, H-30), 0.88 (3H, s, H-23), 0.87 (3H, s, H-24), 0.80 (3H, s, H-28), 0.79 (3H, d, $J=4.0 \mathrm{~Hz}, \mathrm{H}-29) .{ }^{13} \mathrm{C}-\mathrm{NMR}(125$ $\left.\mathrm{MHz}, \mathrm{CDCl}_{3}\right) \delta_{\mathrm{C}} 170.96\left(\mathrm{CH}_{3} \mathrm{CO}\right), 139.64(\mathrm{C}-13), 124.34(\mathrm{C}-12), 80.96(\mathrm{C}-3), 59.09(\mathrm{C}-18), 55.29(\mathrm{C}-5), 47.67$ (C-9), 42.09 (C-14), 41.55 (C-22), 40.05 (C-8), 39.67 (C-19), 39.62 (C-20), 38.49 (C-1), 37.72 (C-4), 36.81 (C-10), 33.76 (C-17), 32.89 (C-7), 31.26 (C-21), 28.75 (C-23), 28.11 (C-28), 28.08 (C-15), 26.62 (C-16), 23.62 (C-2), 23.38 (C-11), 23.24 (C-27), 21.39 (C-30), 21.29 ( $\left.\mathrm{CH}_{3} \mathrm{CO}\right), 18.26$ (C-6), 17.50 (C-29), 16.88 (C-26), 16.74 (C-24), $15.73(\mathrm{C}-25)$.

3ק-Acetoxy-11 $\alpha$-hydroxy-12-ursene (2): White solid. ${ }^{1} \mathrm{H}-\mathrm{NMR}\left(500 \mathrm{MHz}, \mathrm{CDCl}_{3}\right) \delta_{\mathrm{H}} 5.19(1 \mathrm{H}, \mathrm{d}, J=3.5 \mathrm{~Hz}$, $\mathrm{H}-12), 4.52(1 \mathrm{H}, \mathrm{dd}, J=10.0,6.5 \mathrm{~Hz}, \mathrm{H}-3), 4.24(1 \mathrm{H}, \mathrm{dd}, J=9.0,4.0 \mathrm{~Hz}, \mathrm{H}-11), 2.04\left(3 \mathrm{H}, \mathrm{s}, \mathrm{CH}_{3} \mathrm{CO}\right), 1.16(3 \mathrm{H}$, s, H-27), 1.12 (3H, s, H-24), 1.06 (3H, s, H-26), 0.93 (3H, s, H-30), 0.89 (6H, s, H-23\&H-25), 0.86 (3H, d, J= 5.5 $\mathrm{Hz}, \mathrm{H}-29), 0.80$ (3H, s, H-28). ${ }^{13} \mathrm{C}-\mathrm{NMR}\left(125 \mathrm{MHz}, \mathrm{CDCl}_{3}\right) \delta_{\mathrm{C}} 170.93\left(\mathrm{CH}_{3} \mathrm{CO}\right), 142.90(\mathrm{C}-13), 128.75(\mathrm{C}-12)$, 80.70 (C-3), 68.36 (C-11), 58.16 (C-18), 55.77 (C-9), 55.43 (C-5), 43.30 (C-8), 42.15 (C-14), 41.31 (C-22), 40.51 (C-1), 39.42 (C-20), 39.30 (C-19), 37.99 (C-4), 33.64 (C-7), 33.61 (C-17), 31.09 (C-21), 28.67 (C-28), 28.22 (C-22), 27.94 (C-16), 26.69 (C-15), 23.77 (C-2), 23.12 (C-27), 21.32 (C-30), 21.30 ( $\left.\mathrm{CH}_{3} \mathrm{CO}\right), 18.25$ (C-6), 17.99 (C-26), 17.57 (C-29), 16.77 (C-24\&C-25).

p-Coumaric acid (3): White solid. ${ }^{1} \mathrm{H}-\mathrm{NMR}\left(500 \mathrm{MHz}, \mathrm{CD}_{3} \mathrm{OD}\right): \delta_{\mathrm{H}} 7.66(1 \mathrm{H}, \mathrm{d}, J=16.0 \mathrm{~Hz}, \mathrm{H}-7), 7.46(2 \mathrm{H}$, $\mathrm{d}, J=8.5 \mathrm{~Hz}, \mathrm{H}-2 \& \mathrm{H}-6), 6.82\left(2 \mathrm{H}, \mathrm{d}, J=8.5 \mathrm{~Hz}, \mathrm{H}-3 \& \mathrm{H}-5,6.40(1 \mathrm{H}, \mathrm{d}, J=16.0 \mathrm{~Hz}, \mathrm{H}-8) .{ }^{13} \mathrm{C}-\mathrm{NMR}(125 \mathrm{MHz}\right.$, $\left.\mathrm{CD}_{3} \mathrm{OD}\right): \delta_{\mathrm{C}} 168.72(\mathrm{C}-9), 161.16(\mathrm{C}-4), 146.56$ (C-7), 131.10 (C-2\&C-6), 127.32 (C-1), 116.80 (C-3\&C-5), $115.39(\mathrm{C}-8)$. 
Isovitexin (4): Yellow solid. ${ }^{1} \mathrm{H}-\mathrm{NMR}\left(500 \mathrm{MHz}, \mathrm{CD}_{3} \mathrm{OD}\right): \delta_{\mathrm{H}} 7.76\left(1 \mathrm{H}, \mathrm{d}, J=8.0 \mathrm{~Hz}, \mathrm{H}-2{ }^{\prime} \& \mathrm{H}-6\right.$ '), $6.90(1 \mathrm{H}$, $\left.\mathrm{d}, J=8.0 \mathrm{~Hz}, \mathrm{H}-3^{\prime} \& \mathrm{H}-5^{\prime}\right), 6.51(1 \mathrm{H}, \mathrm{s}, \mathrm{H}-3), 6.43(1 \mathrm{H}, \mathrm{s}, \mathrm{H}-8), 4.92\left(1 \mathrm{H}, \mathrm{d}, J=10.0 \mathrm{~Hz}, \mathrm{H}-1^{\prime \prime}\right), 4.22-4.18(1 \mathrm{H}, \mathrm{m}$, H-2"), $3.92\left(1 \mathrm{H}, \mathrm{dd}, J=12.0,2.0 \mathrm{~Hz}, \mathrm{H}-6 \mathrm{a}^{\prime \prime}\right), 3.79\left(1 \mathrm{H}, \mathrm{dd}, J=12.0,5.5 \mathrm{~Hz}, \mathrm{H}-6 \mathrm{~b}^{\prime \prime}\right), 3.53\left(1 \mathrm{H}, \mathrm{m}, \mathrm{H}-4^{\prime \prime}\right), 3.51(1 \mathrm{H}$, m, H-3"), 3.48-3.44 (1H, m, H-5"). ${ }^{13} \mathrm{C}-\mathrm{NMR}\left(125 \mathrm{MHz}, \mathrm{CD}_{3} \mathrm{OD}\right): \delta_{\mathrm{C}} 183.88$ (C-4), 166.02 (C-2), 164.81 (C-7), 162.69 (C-4'), 161.91 (C-5), 158.58 (C-9), 129.35 (C-2'\&C-6'), 122.99 (C-1'), 117.00 (C-3'\&C-5'), 109.09 (C-6), 105.15 (C-10), 103.78 (C-3), 95.29 (C-8), 82.54 (C-5"), 80.12 (C-3"), 75.30 (C-1"), 72.60 (C-2"), 71.74 (C-4"), $62.77\left(\mathrm{C}-6^{\prime \prime}\right)$.

\section{Discussion}

The structure of 1 was determined to be $\mathrm{C}_{32} \mathrm{H}_{52} \mathrm{O}_{2}$ with the aid of spectral comparison of NMR and ESI-MS ion at $\mathrm{m} / \mathrm{z} 469.6[\mathrm{M}+\mathrm{H}]^{+}$. The ${ }^{13} \mathrm{C}-\mathrm{NMR}$ and heteronuclear single-quantum correlation (HSQC) spectra displayed 32 carbon atoms inclusive: a carbonyl $\left(\delta_{\mathrm{C}} 170.96\right)$, nine methylene, seven methine, nine methyl, six quaternary. The proton nuclear magnetic resonance ( $\left.{ }^{1} \mathrm{H}-\mathrm{NMR}\right)$ spectrum of $\mathbf{1}$ displayed signals characteristic for a triterpene of the ursan-12-ene skeleton, eght methyl carbon signals inclusive: six tertiary methyl groups $\left[\delta_{\mathrm{H}} 1.07(3 \mathrm{H}, \mathrm{s}, \mathrm{H}-27)\right.$, $1.01(3 \mathrm{H}, \mathrm{s}, \mathrm{H}-26), 0.98(3 \mathrm{H}, \mathrm{s}, \mathrm{H}-25), 0.88(3 \mathrm{H}, \mathrm{s}, \mathrm{H}-23), 0.87(3 \mathrm{H}, \mathrm{s}, \mathrm{H}-24), 0.80(3 \mathrm{H}, \mathrm{s}, \mathrm{H}-28)]$ and two methyl groups $\left[\delta_{\mathrm{H}} 0.93(3 \mathrm{H}, \mathrm{d}, J=6.0 \mathrm{~Hz}, \mathrm{H}-30), 0.79(3 \mathrm{H}, \mathrm{d}, J=4.0 \mathrm{~Hz}, \mathrm{H}-29)\right]$, a proton of (>C=C-) group $\left[\delta_{\mathrm{H}} 5.13\right.$ $(1 \mathrm{H}, \mathrm{t}, J=3.5 \mathrm{~Hz}, \mathrm{H}-12)]$. The ${ }^{1} \mathrm{H}-,{ }^{13} \mathrm{C}-\mathrm{NMR}$ spectrum of 1 exhibited signals characteristic of a acetoxy group, a oxymethine group $\left[\delta_{\mathrm{H}} 4.52-4.49(1 \mathrm{H}, \mathrm{m}) ; \delta_{\mathrm{C}} 80.96\right]$, a acetyl group $\left[\delta_{\mathrm{H}} 2.04\left(3 \mathrm{H}, \mathrm{s}, \underline{\mathrm{CH}_{3}} \mathrm{CO}\right), \delta_{\mathrm{C}} 170.96\left(\mathrm{CH}_{3} \underline{\mathrm{CO}}\right)\right.$, $\left.21.29\left(\mathrm{CH}_{3} \mathrm{CO}\right)\right]$. The exact acetoxy group were located at $\mathrm{C}-3$ additional $\mathrm{HMBC}$ correlations between the protons $\mathrm{H}-23\left(\delta_{\mathrm{H}} 0.88\right), \mathrm{H}-24\left(\delta_{\mathrm{H}} 0.87\right)$ and carbon C-3 $\left(\delta_{\mathrm{C}} 80.96\right) ; \mathrm{H}-3\left(\delta_{\mathrm{H}} 4.51\right)$ and carbons C-23 $\left(\delta_{\mathrm{C}} 28.75\right), \mathrm{C}-24\left(\delta_{\mathrm{C}}\right.$ 16.74). From the above spectral data and with published data [13], the structure of 1 was determined to be $\alpha$-amyrin acetate.

Combining all of the above ${ }^{1} \mathrm{H}-,{ }^{13} \mathrm{C}-\mathrm{NMR}$, HSQC spectra data and ESI-MS ion at $\mathrm{m} / \mathrm{z} 485.6[\mathrm{M}+\mathrm{H}]^{+}$the structure of 2 was determined to be $\mathrm{C}_{32} \mathrm{H}_{52} \mathrm{O}_{2}$. Combining all of the MS, NMR spectral data showed that compounds $\mathbf{2}$ and $\mathbf{1}$ indicated they had the same skeleton and $\mathbf{2}$ connect an $-\mathrm{OH}$ group, the presence of an $-\mathrm{OH}$ group was indicated by the observed resonance at $\delta_{\mathrm{H}} 4.24(1 \mathrm{H}, \mathrm{dd}, J=9.0,4.0 \mathrm{~Hz})$ and $\delta_{\mathrm{C}} 68.36$. The HMBC correlations between the proton oxymethine $\mathrm{H}-11\left(\delta_{\mathrm{H}} 4.24\right)$ and $\mathrm{C}-9\left(\delta_{\mathrm{C}} 55.77\right), \mathrm{C}-12\left(\delta_{\mathrm{C}} 128.75\right)$, determined the hydroxy group to be at $\mathrm{C}-5$. The hydroxyl group is bonded to an $\alpha$-carbon atom was indicated by correlations between the proton $\mathrm{H}-9$ and $\mathrm{H}-11, J=9.0 \mathrm{~Hz}$. Comparison with ${ }^{13} \mathrm{C}$-NMR spectroscopic data of $3 \beta$-acetoxy-11 $\alpha$-hydroxy-12-ursene reported in the literature [14] for same compounds. Combining all of the above information, the structure of 2 was determined to be $3 \beta$-acetoxy- $11 \alpha$-hydroxy-12-ursene.

The proton nuclear magnetic resonance $\left({ }^{1} \mathrm{H}-\mathrm{NMR}\right)$ spectrum of $\mathbf{3}$ displayed signals characteristic for four aromatic protons of system is $\mathrm{AA}^{\prime} \mathrm{BB}^{\prime}$ at $\delta_{\mathrm{H}} 6.82(2 \mathrm{H}, \mathrm{d}, J=8,5 \mathrm{~Hz}), 7.46(2 \mathrm{H}, \mathrm{d}, J=8,5 \mathrm{~Hz})$ and two carbons of the trans-olefin have a very large chemical shift difference at $\delta_{\mathrm{H}} 7.66(1 \mathrm{H}, \mathrm{d}, J=16.0 \mathrm{~Hz}), 6.34(1 \mathrm{H}, \mathrm{d}, J=16,0 \mathrm{~Hz})$. The 13C-NMR spectra displayed nine carbon atoms inclusive: a carbonyl at $\delta_{\mathrm{C}} 168.72$, six methine carbon and two quaternary composed of a quaternary carbon atom bonded to an oxygen atom at $\delta_{\mathrm{C}} 146.6$. From the above spectral data and with published data [15], the structure of $\mathbf{3}$ was determined to be $p$-coumaric acid.

The proton nuclear magnetic resonance $\left({ }^{1} \mathrm{H}-\mathrm{NMR}\right)$ spectrum of compound $\mathbf{4}$ displayed signals characteristic of a flavonoid for four aromatic protons of system is AA'BB' at $\delta_{\mathrm{H}} 7.76\left(1 \mathrm{H}, \mathrm{d}, J=8.0 \mathrm{~Hz}, \mathrm{H}-2^{\prime} \& \mathrm{H}-6^{\prime}\right), 6.90(1 \mathrm{H}, \mathrm{d}$, $\left.J=8.0 \mathrm{~Hz}, \mathrm{H}-3^{\prime} \& \mathrm{H}-5^{\prime}\right)$ and singles at $\delta_{\mathrm{H}} 6.51(1 \mathrm{H}, \mathrm{s}, \mathrm{H}-3), 6.43(1 \mathrm{H}, \mathrm{s}, \mathrm{H}-8)$. The signals characteristic of a glucose unit inclusive: a oxymethylene at $\left[\delta_{\mathrm{H}} 3.92\left(1 \mathrm{H}, \mathrm{dd}, J=12.0,2.0 \mathrm{~Hz}, \mathrm{H}-6 \mathrm{a}^{\prime \prime}\right), 3.79(1 \mathrm{H}, \mathrm{dd}, J=12.0,5.5\right.$ $\left.\left.\mathrm{Hz}, \mathrm{H}-6 \mathrm{~b}^{\prime \prime}\right), \delta_{\mathrm{C}} 62.77\right]$ and five oxymethine at $\left[\delta_{\mathrm{H}} 4.22-3.44, \delta_{\mathrm{C}} 82.54-71.74\right]$. The HSQC spectrum the correlations between proton anomeric at $\left(\delta_{\mathrm{H}} 4.92\right)$ and a quaternary carbon at $\left(\delta_{\mathrm{C}} 75.30\right)$, show that C-linkage/glycosidic bond. Direct carbon-proton coupling constants $J=10.0 \mathrm{~Hz}$ are $\beta$-D-glucopyranose configuration. The ${ }^{1} \mathrm{H}-,{ }^{13} \mathrm{C}-\mathrm{NMR}$ spectra compound 4 displayed signals 15 carbon atoms of a flavonoid inclusive: nine quaternary carbon, six methine and six carbon atoms of a glucose unit at $\delta_{\mathrm{C}} 82.54-62.77 \mathrm{ppm}$. The HMBC correlations between the proton $\mathrm{H}-1^{\prime \prime}\left(\delta_{\mathrm{H}} 4.92\right)$ and carbon atoms at C-5 $\left(\delta_{\mathrm{C}} 161.91\right)$, C-6 $\left(\delta_{\mathrm{C}} 109.09\right)$ và $\mathrm{C}-7\left(\delta_{\mathrm{C}} 164.81\right)$ show that $\mathrm{C}_{6^{-}}$ glycosidic bond. From the above spectral data and with published data [16], the structure of 4 was determined to be isovitexin. 


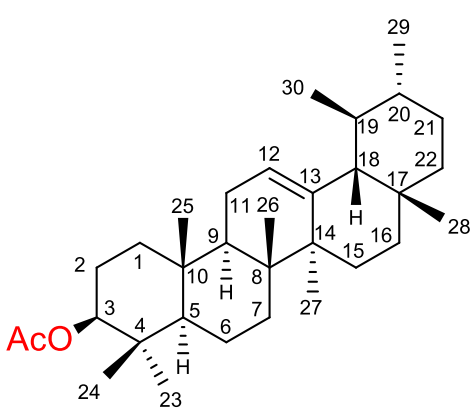

1

3<smiles>O=C(O)C=Cc1ccc(O)cc1</smiles>

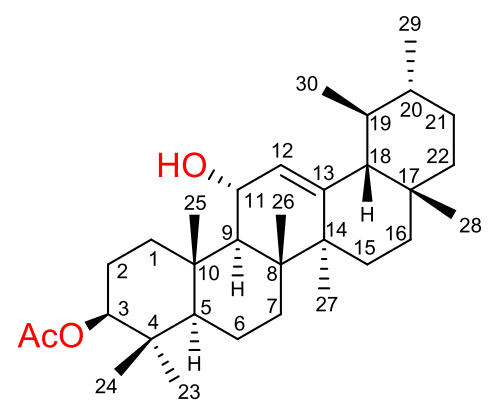

2<smiles>C[C@@H](O)C[C@@H](O)c1c(O)cc2oc(-c3ccc(O)cc3)cc(=O)c2c1O</smiles>

Figure 1. Chemical structures of compounds 1-4 isolated from the leaves of $F$. hirta.

Compounds 2 and 4 were discovered in leaves of $F$. hirta for the fist time collected in Yen Son district, Tuyen Quang province, Vietnam. Compounds 1 widely distributed in genus Ficus inclusive: Ficus sur, Ficus exasperate, Ficus bengalensis and roots of $F$. hirta. Compound 1 has anti-inflammatory activities [17], lowering the glucose level in the blood [18]. Compound $\mathbf{3}$ was discovered in roots of $F$. hirta in China [8]. Compound $\mathbf{4}$ was discovered in leaves of Ficus deltoidea [19].

\section{Conclusion}

From $n$-hexane and $n$-butanol extracts leaves of Ficus hirta collected in Yen Son district, Tuyen Quang province, Vietnam, four compounds were isolated and chemical structurally elucidated, namely pinoresinolv $\alpha$-amyrin

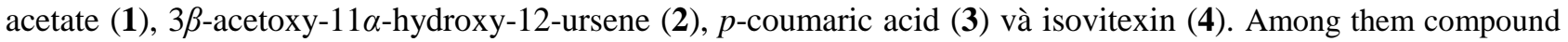
4 was identified for the first time in this plant. Their chemical structures were confirmed by spectroscopic methods including MS, 1D-, 2D NMR and compared with reported data.

\section{Consent For Publication}

Not applicable.

\section{Conflict of Interest}

The authors declare no conflict of interest, financial or otherwise.

\section{Acknowledgement}

Financial support was provided by a grant from Tan Trao University. We thank Dr. Nguyen The Hai, Faculty of Medicine and Pharmacy, Tan Trao University for Identification of Plant Samples. We thank Dr. Nguyen Thanh Tam et... - Laboratory of Natural Products Research, Institute of Chemistry, Vietnam Academy of Acience and Technology for the laboratory.

\section{References}

[1] T.- M. Shao, C.-J. Zheng, C.-R. Han, G.-Y. Chen, C.-Y. Dai, X.-P. Song, J.-C. Zhang, and W.-H. Chen. (2014). Lactones from Ficus auriculata and their effects on the proliferation function of primary mouse osteoblasts in vitro. Bioorganic \& Medicinal Chemistry Letters 24 , 3952-3955.

[2] Pham Hoang Ho. (2000). Illustrated flora of Vietnam, Young Publishing house, Ho Chi Minh, Vietnam. Vol 2, pp. $551-581$. 
[3] Do Tat Loi. (2004). Vietnamese medicinal plants and herbs. Medicine Publishing House, pp. 915.

[4] Chuying Chen, Xuan Peng, Jinyin Chen, and Chunpeng Wan. (2020). Antioxidant, Antifungal Activities of Ethnobotanical Ficus hirta Vahl. Analysis of Main Constituents by HPLC-MS. Biomedicines. 8, 15.

[5] Ya J, Zhang XQ, Wang Y, Zhang QW, Chen JX, and Ye WC. (2010). Two new phenolic compounds from the roots of Ficus hirta. Nat Prod Res. 24,621-625.

[6] Zheng RR, Wang WJ, Yang HB, Zhang QW, Zhang XQ, and Ye WC. (2013). Chemical studies on roots of Ficus hirta. China Journal of Chinese Materia Medica. 38, 3696-3701.

[7] Cheng J, Yi X, Wang Y, Huang X, and He X. (2017). Phenolics from the roots of hairy fig (Ficus hirta Vahl.) exert prominent anti-inflammatory activity. Journal of Functional Foods. 31, 79-88.

[8] Cheng J, Yi X, Chen H, Wang Y, and He X. (2017). Anti-inflammatory phenylpropanoids and phenolics from Ficus hirta Vahl. Fitoterapia 121, 229-234.

[9] Wan C, Chen C, Li M, Yang Y, Chen M, and Chen J. (2017). Chemical constituents and antifungal activity of Ficus hirta Vahl. Fruits. Plants. 6, 44-52.

[10] T. D. Dai, N. T. Tam, D. D. Thien, N. H. Sa, T. T. Thuy, N. T. H. Anh, and T. D. Quan (2018). A New furanocoumarin glycoside from the roots of Ficus hirta. Letters in Organic Chemistry. 15, 1007-1011.

[11] D. D. Thien, T. D. Dai, N. T. T. Huong, V. T. Huong, N. H. Sa, T. T. Thuy, N. T. H. Anh, T. D. Quan, and N. T. Tam. (2018). Phenolics from the roots of Ficus hirta. Vietnam Journal of Chemistry 56(4e), 32-35.

[12] D. D. Thien, T. D. Dai, N. H. Sa, N. T. Lieu, T. T. Thuy, N. T. H. Anh, T. D. Quan, L. Q. Thang, D. V. Delfino, and N. T. Tam. (2019). A new oleanane triterpene from the leaves of Ficus hirta. Natural Product Research 33(21), 3065-3069.

[13] Zong-Shiow Chen, Jeng-Shiow Lai, and Yueh-Hsiung Kuo. (1991). Cynanformosides A and B, two new pregnane glycosides, from the aerial part Cynanchum formosanum. Chem. Pharm. Bull 39(11), 3034-3036.

[14] Yueh-Hsiung and Yi-Ming Chiang. (2000). Six new ursane-and oleanane-type triterpenes from the aerial roots of Ficus microcarpa. Chem. Pharm. Bull., 48(5), 593-596.

[15] Dang Ngoc Quang, Tran Cong So, Nguyen Thi Phuong Thanh, Le Thi Phuong Hoa, Pham Huu Dien, Truong Minh Luong, Nguyen Quang Tung, Le Duc Long, Tran Duc Dai, and Nguyen Quyet Tien. (2018). Balanochalcone, a new chalcone from Balanophora laxiflora Hemsl. Natural Product Research, 32(7), 767-772.

[16] Le Canh Viet Cuong, Do Thi Trang, Nguyen Thi Cuc, Nguyen Xuan Nhiem, Pham Hai Yen, Hoang Le Tuan Anh, Le Mai Huong, Chau Van Minh, and Phan Van Kiem. (2015). Flavonoid glycosides from Antidesma ghaesembilla. Vietnam Journal of Chemistry, 53(2e), 94-97.

[17] N.N. Okoye, D.L. Ajaghaku, H.N. Okeke, E.E. Ilodigwe, C.S. Nworu, and F.B. Okoye. (2014). $\beta$-Amyrin and $\alpha$-amyrin acetate isolated from the stem bark of Alstonia boonei display profound anti-inflammatory activity. Pharm Biol, 52(11), 1478-1486.

[18] A.B. Singh, D.K. Yadav, R. Maurya, and A.K. Srivastava. (2009). Antihyperglycaemic activity of alpha-amyrin acetate in rats and db/db mice. Natural Product Research, 23(9), 876-882.

[19] N.Y. Sulong, F. Man, and T.W. Wong. (2012). Vitexin and isovitexin from the Leaves of Ficus deltoidea with in-vivo $\alpha$-glucosidase inhibition. Journal of Ethnopharmacology, 142(3), 776-781. 